\title{
Influence of EAPI Skills Training Course on the Knowledge, Attitude, and Practice of Undergraduate University Students: A Case of the EAPI Program, Uganda
}

\author{
Julia Kigozi (Corresponding author) \\ Department of Agricultural and Bio-systems Engineering, Makerere University \\ P. O. Box 7062, Kampala, Uganda \\ Tel: +256-772-609-649 E-mail: jbulyakigozi@yahoo.com

\begin{abstract}
Emmanuel Baidhe
Department of Agricultural and Bio-systems Engineering, Makerere University

P. O. Box 7062, Kampala, Uganda
\end{abstract}

Ivan Muzira Mukisa

Department of Food Technology and Nutrition, Makerere University

P. O. Box 7062, Kampala, Uganda

Charles Muyanja

Department of Food Technology and Nutrition, Makerere University

P. O. Box 7062, Kampala, Uganda

Leatitiah Namubiru

Uganda National Bureau of Standards (UNBS)

P. O. Box 6329, Kampala, Uganda 


\title{
Brenda Katarikawe
}

Uganda Export Promotion Board (UEPB)

P. O. Box 5045, Kampala, Uganda

Received: January 26, 2021

Accepted: April 22, $2021 \quad$ Published: June 25, 2021

doi:10.5296/ijld.v11i2.18807

URL: https://doi.org/10.5296/ijld.v11i2.18807

\begin{abstract}
Upon employment, fresh graduates have been widely criticized for their underperformance due to their lack of relevant practical skills. Furthermore, students need training that allows them to blend knowledge with the practice in the workspace. This study assessed the influence of an 'Empowerment of the Agro-processing Industry (EAPI)' skills training for the agro-processing industry, on the knowledge, attitude, and practice among students in the School of Food Technology Nutrition and Bio-Engineering (SFTNB), Makerere University. Students were trained in 8 modules including; food process and value-chain management, food product optimization, national and international standards of food products, application of good management practices (GMP) and hygienic food processing, quality control in food production processes, waste management, infrastructure development to meet quality \& production capacity in food production facilities and food product marketing \& preparation for export markets. A semi-structured questionnaire with a descriptive, scale and thematic analysis was used to evaluate the impact of the training. The reliability of the responses of the questionnaires was tested using Cronbach's alpha and they showed high reliability; yielding values that ranged between 0.88 and 0.97 . Results showed a statistically significant difference $(\mathrm{p}<0.05)$ in knowledge, attitude and practice for product optimization, adequate processing facility, standardization, certification, and export marketing. Cronbach's alpha values ranged between 0.88 and 0.97 for all stated variables indicating that the scales were sound and reliable. Therefore, the inclusion of similar study material into the current curriculum would help improve and enrich the curriculum thereby producing well-prepared students for the food processing industry in Uganda.
\end{abstract}

Keywords: Short off-the-job training; Students; Knowledge, Attitude, and Practice; Food processing industry; Uganda 


\section{Introduction}

Training programs have for long been utilized to polish and improve skills among human resources. Training is considered as a process for changing and developing behavior, knowledge, skill, and motivation of employees (Hussein \& Ebru, 2016). According to Nda and Fard (2013), training is a series of activities embarked upon by an organization that leads to knowledge or skills acquisition for growing purposes. A study by Salah (2016) recommends that employees should engage in all self-development opportunities provided to them so that they become a knowledge-based person. The study adds that training not only increases organizational productivity but equally enhances skills among employees, therefore, preparing them for future challenges. It is therefore important that students intending to join the working class be given strategic skills relevant to their fields. Some university graduates volunteer as a form of On-the-job (OJT) training in a way to align their abilities to the industry at hand. Marinescu and Toma (2013) reports that trainings are critical pathways for acquiring information, knowledge, and guidance towards the rapidly changing work environments. The use of Off-the-job-training (OFJT) could help redeem the employability of these graduates, as On-the-Job Training (OJT) consumes a lot of time. Off-the-job-training involves the use of group discussions, one-on-one tutorials, lecture readings, training courses, and workshops (Milhem, Abushamsich, \& Aróstegui, 2014). According to Milhem et al. (2014), this form of training enables trainees to learn and apply new skills and knowledge in a safe working context as it empowers the trainee prior to actual practice. The trainee is less likely to be exposed to health and safety threats that would otherwise be experienced with the OJT.

Most universities including Makerere University use a lecture-based training system as way to deliver knowledge to students (Gregory, 2013; Islam, Kim, \& Kwon, 2020). Lecture-based training is considered to be simple, fast and cheap way to deliver knowledge to the students (Sadeghi, Sedaghat, \& Sha Ahmadi, 2014). However, the traditional lecture-based training has a number of limitations. Lectures are often teacher-centered with minimal student engagement. Some researchers have associated the lecture-based training to limited student motivation, therefore encouraging superficial learning such as cramming for purposes of passing the exams (Afurobi, Izuagba, Obiefuna, \& Ifegbo, 2015; Gregory, 2013). Lecture-based training is characterized by a unidirectional transfer of knowledge (Zeng, Chen, Li, \& Wang, 2020). Lecture-based learning has well-designed delivery methods that sometimes may not account for the varying learners' needs. About $80 \%$ of the content presented using the traditional lecture-based training is forgotten within the first 8 weeks (Sadeghi et al., 2014). There is need to device alternative methods to improve knowledge retention among students.

Several studies have proposed the use of more active-learning methods for students at higher institutions of learning to improve retention of knowledge (Shaaruddin \& Mohamad, 2017). Active learning encompasses all instructional methods that support students to learn through continual student engagement. Active learning can be in the form of seminars, group discussions, presentations, role playing, collaborative learning groups among others. Compared to the traditional lecture-training, active learning is a student-centered form of 
learning. Active learning fosters great attributes such as growth in creative and critical thinking, adaptability, communication (Awang \& Daud, 2015) and interpersonal skills among students.

The Empowerment of the Agro-Processing Industry (EAPI) to meet the Quantity and Quality Standards for the Local and Export Market; a Programme Enhancing the Practical Skills of Students in Makerere University (EAPI Project) organized a three-day modular training for students targeting to empower them in skills relevant for the food processing industry. The training used student-processor peer interactive sessions to help students compliment the knowledge gained through their lecture-based training. It was of interest to study the effect of the training on the student growth in knowledge, attitudes, and practice of the skills relevant for the food processing industry. The study findings have important implications on the development of an appropriate University curriculum to best improve the nature of students graduating from university as well as national policies that enable a thriving Food processing industry.

\section{Methodology}

\subsection{Study Population}

The population comprised 40 second, third and fourth-year undergraduate students of food processing of Makerere University with the following background: (i) Food Science and Technology (FST); (ii) Agricultural Engineering (AGE); (iii) Applied Human Nutrition (HMN). A general invitation was posted on the School of Food Technology Nutrition and Bioengineering noticeboards for students to apply to attend for the training. This was to ensure that students who participated had a personal interest in the training. Second, third, and fourth years of study were considered since students at that level are to a greater extent grounded in the science and practice compared to the first-year students who are under inauguration. A total population purposive sampling technique was used as only students that attended the EAPI Project skills training participated in the study. Also, the number of students was relatively small (Etikan, Abubakar, \& Alkassim, 2016).

\subsection{Overview of the Training}

The EAPI Project three-day training was conducted from the $6^{\text {th }}$ to $8^{\text {th }}$ of February 2020 at the School of Food Technology, Nutrition and Bio-engineering Conference Hall, Makerere University. Eight scientific modules were co-developed and reviewed by experts based at Makerere University's Department of Food Technology and Nutrition, Uganda National Bureau of Standards (UNBS), and Uganda Export Promotions Board (UEPB). The modules were delivered to participants in a modular manner, each lasting about 1.5 to $2 \mathrm{~h}$. The scientific modules included; (i) Process and value chain management, (ii) Product optimization, (iii) General Manufacturing Practices (GMPs), (iv) Quality control and quality assurance, (v) Waste management, (vi) Standards, (vii) Marketing, and (viii) Infrastructural development. During the training, each student was attached to a processor to create a student-processor interaction especially during the execution of training assignments. The 40 agro-processors based in Uganda shared their experiences and practices related to the subjects 
under discussion with students during the training.

\subsection{Data Collection}

The data was collected through the use of semi-structured paper-based questionnaires. Simple instructions and assistance were given to ensure that the questionnaires were correctly filled. Also, the confidentiality of the information was assured with an informed consent and confidentiality clause. The questionnaire comprised of eight sections (appendix). Section 1 focused on bio-data. In section 2, the respondents were asked to rate the level of training they had ever received before the EAPI training, to enhance their knowledge (K), attitude (A), and practices $(\mathrm{P})$ for the target agro-processing skills. The level of training before the EAPI course was evaluated based on a 4-point Likert scale (1- Never, 2- Once in class, 3- Short training, and 4- Very well). In section 3, the level of impact on their KAP's after the training was estimated for all the target agro-processing skills. The agro-processing skills included product optimization, documentation, Good Manufacturing Practices (GMPs) and Hygiene practices, quality control, waste management, adequate processing facility, adequate equipment, standardization, certification, and marketing strategies. Section 3 was evaluated using a 4-point Likert scale with scores from 1 - Not at all, 2 - To a small extent, 3 Moderately, and 4 - To a great extent. Section 4 assessed the extent to which the training modules were relevant to the students. In section 5, respondents were asked to assess the extent to which the different practices are included in the curriculum. Sections 4 and 5 was evaluated based on a 4-point Likert scale (1 - Not at all, 2 - To a small extent, 3 - Moderately, and 4 - To a great extent). The scale describes the extent to which the respondent agrees with each item in the questionnaire. Sections 6,7 , and 8 are qualitative. The respondents were asked to suggest ways in which some of the modules could be included in the curriculum; suggest other modules in relation to agro-processing that they would want included in the curriculum; the aspects of the training that could be improved; and the changes that respondents anticipate to see as a result of the training.

\subsection{Data Analysis}

Data analysis was carried out using MS Excel 2019. Descriptive, scale, and thematic analysis were used to evaluate the impact of the training on the knowledge, attitudes, and practice of food processing students. Descriptive analysis such as frequencies, percent, means, and standard deviations were used to elaborate on the proportion of respondents choosing the various responses. A paired t-test at $95 \%$ confidence interval was done using Genstat $14^{\text {th }}$ Edition software to evaluate the difference between KAP before and after the training. Also, tables and graphs were used to ease the understanding of the analyses. Reliability tests were done using Cronbach's alpha measure. According to Riley et al. (2003), a reliability coefficient of above $0.7(70 \%)$ is considered acceptable.

\section{Results and Discussion}

\subsection{Response Rate}

Of the 40 questionnaires issued out, only 34 were returned. Therefore, the response rate was $85 \%$. Tiberious, Mwania, and Mwinzi (2016) reports that a response rate of 50\% is adequate, 


\section{Macrothink}

International Journal of Learning and Development

ISSN 2164-4063

2021, Vol. 11, No. 2

$60 \%$ is good and above $70 \%$ is excellent for analysis and reporting. The response rate was therefore excellent.

\subsection{Demographics}

Table 1 indicates the demographic characteristics of the study sample. By gender, the male and female representation was $63 \%$ and $32 \%$ respectively. This could be attributed to the low involvement of females in scientific academic programs. Many females continue to consider science and technology programs as being hard and suitable for men (Dimitriada, 2013). More human nutrition (HMN) students (44\%) participated in the study compared to Food Science and Technology (FST) and Agricultural Engineering (AGE) students at 32\% and $24 \%$ respectively. Regarding the year of study, the majority of the participants were third-year undergraduate students (67\%). The other groups participated almost equally with the second years, fourth years, and the others standing at $9 \%, 12 \%$, and $12 \%$ respectively. Of the third-year undergraduate students, the majority $(52 \%, \mathrm{n}=23)$ were from $\mathrm{HMN}$, followed by FST and AGE with $35 \%$ and $13 \%$ respectively as depicted in Table 2 . These could have been inspired by the fact that they are attending their final year at the university. The fourth-year was dominated by AGE and FST as HMN is a three-year program.

Table 1. Demographic characteristics, frequencies, and proportions

\begin{tabular}{lll}
\hline Item & Freq $(\mathbf{n}=\mathbf{3 4})$ & Proportion \\
\hline Gender & 23 & $68 \%$ \\
Male & 11 & $32 \%$ \\
Female & $\mathbf{3 4}$ & $\mathbf{1 0 0 \%}$ \\
Total & & \\
\hline Program & 8 & $24 \%$ \\
AGE & 11 & $32 \%$ \\
FST & 15 & $44 \%$ \\
HMN & $\mathbf{3 4}$ & $\mathbf{1 0 0 \%}$ \\
Total & & \\
\hline Year of study & 3 & $9 \%$ \\
Undergraduate-Second & 23 & $67 \%$ \\
Undergraduate-Third & 4 & $12 \%$ \\
Undergraduate-Forth & 4 & $12 \%$ \\
Other & $\mathbf{3 4}$ & \\
Total & & $\mathbf{1 0 0 \%}$ \\
\hline
\end{tabular}


Table 2. Cross-tabulation for programs and year of study

\begin{tabular}{|c|c|c|c|c|c|c|c|c|c|}
\hline & \multicolumn{8}{|c|}{ Year of study } \\
\hline & & \multirow{2}{*}{\multicolumn{2}{|c|}{$\begin{array}{l}\text { Undergraduate- } \\
\text { Second }\end{array}$}} & \multirow{2}{*}{\multicolumn{2}{|c|}{$\begin{array}{l}\text { Undergraduate- } \\
\text { Third }\end{array}$}} & \multirow{2}{*}{\multicolumn{2}{|c|}{$\begin{array}{l}\text { Undergraduate- } \\
\text { Forth }\end{array}$}} & \multirow{2}{*}{\multicolumn{2}{|c|}{ Other }} \\
\hline & & & & & & & & & \\
\hline & & Freq. & Percent & Freq. & Percent & Freq. & Percent & Freq. & Percent \\
\hline \multirow{4}{*}{ 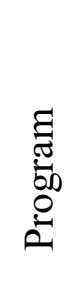 } & AGE & 0 & $0 \%$ & 3 & $13 \%$ & 2 & $50 \%$ & 3 & $75 \%$ \\
\hline & FST & 1 & $33 \%$ & 8 & $35 \%$ & 2 & $50 \%$ & 0 & $0 \%$ \\
\hline & $\mathrm{HMN}$ & 2 & $67 \%$ & 12 & $52 \%$ & 0 & $0 \%$ & 1 & $25 \%$ \\
\hline & Total & 3 & $100 \%$ & 23 & $100 \%$ & 4 & $100 \%$ & 4 & $100 \%$ \\
\hline
\end{tabular}

\subsection{Reliability Analysis}

Responses of the respondents were subjected to a reliability analysis using Cronbach's alpha to establish internal consistency, soundness, and reliability. Cronbach's alpha values are shown in Table 3. Generally, higher values show a more reliable scale. Results for reliability indicates that Cronbach's alpha values range between 0.88 and 0.97 for all stated variables, therefore making the scale sound and reliable (Nunnally \& Bernstein, 1994).

Table 3. Cronbach's alpha values from reliability tests

\begin{tabular}{lcc}
\hline Variable & No. of items & Cronbach's alpha \\
\hline Knowledge, Attitude, and Practices (Before training) & 33 & 0.9487 \\
Knowledge, Attitude, and Practices (After training) & 33 & 0.9779 \\
Relevancy of the modules & 8 & 0.8874 \\
Inclusion of modules in the curriculum & 11 & 0.9422 \\
\hline
\end{tabular}

\subsection{Knowledge, Attitude and Practice before and after training}

The mean scores for before and after the training are shown in Table 4. Overall, the mean scores before the training for knowledge, attitude, and practice of the students in the target skills ranged 2.2-3.2, 2.2-3.3, and 1.7-3.1 respectively. This indicates that the students had either never had training or had received one lesson or had undergone short training in the target skills. Good Manufacturing Practice and hygienic practices module scored highest for student knowledge, attitude, and practice before the training. This could be attributed to the fact that food safety (Results from good manufacturing practices and hygienic practices) is 
often emphasized during their undergraduate training in food processing courses. The marketing module scored lowest for student knowledge while the standards and product certification module scored lowest for both student attitude and practice. This could be linked to the fact that many of the students have not interacted with concepts in the marketing of products. Most of the FST students had not attended FST 3203 Food Plant Economics and Products Marketing, a course unit that directly relates with marketing. The course unit is handled in the second semester of third year of the study program yet the training was conducted at the start of the second semester. This could have had a bearing on the results for the marketing module. The low scores of the standards and certification module for student attitude are likely attributed to their low application in the food industry locally resulting in the high prevalence of non-certified products on the market. In the 2019/2020 financial year alone, the Uganda National Bureau of Standards (UNBS) destroyed 232 metric tons (MT) of substandard goods worth UGX 2.5 Billion (Muhwezi, 2020). As part of the FST program of Makerere University, the FST 3106 Food Quality Assurance course handled in first semester of third year prepares the students in food safety, quality and food legislation. The low scores for standards and certification however indicate that the aspects are not well covered as part of food quality assurance course.

After training, the overall mean for student knowledge, attitude, and practice increased in the target skills, resulting in scores of 2.7-3.4, 2.7-3.4, and 2.3-3.3 respectively. This indicated that the student knowledge and attitude improved to an adequate level while the student practice even when improved, was still inadequate. The waste management module scored highest for student knowledge while GMPs and hygienic practice scored highest for student attitude and practice. This could be attributed to the well-elaborated training in the areas of waste management, GMPs, and Hygienic practices. Some students appreciated that the training enabled them to look at waste as an alternative source of income rather than a burden. Nonetheless, some students note that the module on waste management was conducted in a short time yet with rich concepts. This could have affected its overall score in knowledge. The module on marketing scored lowest in terms of student knowledge, attitude, and practice but indicated a good understanding of the concepts and a need for further practice.

There was a statistically significant difference $(\mathrm{p}<0.05)$ in knowledge, attitude and practice for product optimization, adequate processing facility, standardization, certification, and export marketing (Table 4). The change in KAP for GMPs and Hygienic practices, waste management, and local marketing was generally non-significant. This could be as a result of the nature of the university programs under study that directly focus on food production and processing. 
Table 4. Means and Standard Deviation for Knowledge, Attitude, and Practice before and after training for the different aspects of the training

\begin{tabular}{|c|c|c|c|c|c|c|}
\hline \multirow{2}{*}{ Process } & \multicolumn{3}{|c|}{ Before training } & \multicolumn{2}{|c|}{ After training } & \multirow[b]{2}{*}{ P-value } \\
\hline & Attribute & Mean & SD & Mean & SD & \\
\hline \multirow{3}{*}{ Product optimization } & $\mathrm{K}$ & 2.412 & 0.911 & 3.265 & 0.885 & $<0.001^{*}$ \\
\hline & $\mathrm{A}$ & 2.853 & 1.004 & 3.353 & 0.800 & $0.03 *$ \\
\hline & $\mathrm{P}$ & 1.706 & 0.924 & 2.912 & 0.981 & $<0.001 *$ \\
\hline \multirow{3}{*}{$\begin{array}{l}\text { Documented } \\
\text { chain }\end{array}$} & $\mathrm{K}$ & 2.735 & 1.066 & 3.152 & 1.048 & 0.092 \\
\hline & $\mathrm{A}$ & 2.941 & 1.027 & 3.333 & 1.005 & 0.130 \\
\hline & $\mathrm{P}$ & 2.353 & 1.185 & 3.000 & 1.044 & $0.010^{*}$ \\
\hline \multirow{3}{*}{$\begin{array}{l}\text { GMPs \& Hygienic } \\
\text { practices }\end{array}$} & $\mathrm{K}$ & 3.147 & 0.879 & 3.353 & 0.836 & 0.242 \\
\hline & A & 3.294 & 0.892 & 3.471 & 0.813 & 0.447 \\
\hline & $\mathrm{P}$ & 3.088 & 1.067 & 3.324 & 0.962 & 0.347 \\
\hline \multirow{3}{*}{ Quality control } & $\mathrm{K}$ & 2.676 & 1.130 & 3.303 & 0.904 & $0.018^{*}$ \\
\hline & $\mathrm{A}$ & 2.735 & 1.120 & 3.303 & 0.969 & $0.033^{*}$ \\
\hline & $\mathrm{P}$ & 2.471 & 1.169 & 2.909 & 1.111 & 0.062 \\
\hline \multirow{3}{*}{ Waste management } & $\mathrm{K}$ & 3.088 & 1.067 & 3.412 & 0.771 & 0.169 \\
\hline & $\mathrm{A}$ & 3.000 & 1.111 & 3.176 & 0.954 & 0.505 \\
\hline & $\mathrm{P}$ & 2.529 & 1.169 & 2.824 & 1.150 & 0.201 \\
\hline \multirow{3}{*}{$\begin{array}{l}\text { Adequate } \\
\text { facility }\end{array}$} & $\mathrm{K}$ & 2.441 & 1.090 & 3.000 & 0.939 & $0.006^{*}$ \\
\hline & $\mathrm{A}$ & 2.500 & 1.064 & 3.118 & 0.932 & $0.007^{*}$ \\
\hline & $\mathrm{P}$ & 2.059 & 1.056 & 2.727 & 0.930 & $<0.001 *$ \\
\hline \multirow{3}{*}{ Adequate equipment } & $\mathrm{K}$ & 2.529 & 1.007 & 3.061 & 0.851 & $0.034^{*}$ \\
\hline & $\mathrm{A}$ & 2.647 & 0.997 & 2.909 & 0.933 & 0.169 \\
\hline & $\mathrm{P}$ & 2.265 & 1.066 & 2.636 & 0.979 & 0.060 \\
\hline \multirow{3}{*}{ Standardization } & $\mathrm{K}$ & 2.324 & 1.254 & 3.091 & 0.965 & $<0.001^{*}$ \\
\hline & $\mathrm{A}$ & 2.559 & 1.217 & 3.242 & 0.889 & $0.003 *$ \\
\hline & $\mathrm{P}$ & 1.794 & 1.079 & 2.909 & 0.996 & $<0.001^{*}$ \\
\hline
\end{tabular}




\begin{tabular}{lllllll}
\hline & $\mathrm{K}$ & 2.294 & 1.151 & 3.061 & 0.983 & $0.002^{*}$ \\
Certification & $\mathrm{A}$ & 2.265 & 1.120 & 3.121 & 1.094 & $0.001^{*}$ \\
& $\mathrm{P}$ & 1.765 & 0.972 & 2.848 & 1.077 & $<0.001^{*}$ \\
\hline \multirow{2}{*}{ Marketing Local } & $\mathrm{K}$ & 2.382 & 1.000 & 2.719 & 1.007 & 0.103 \\
& $\mathrm{~A}$ & 2.441 & 0.945 & 2.781 & 1.082 & 0.140 \\
& $\mathrm{P}$ & 2.000 & 0.767 & 2.313 & 1.073 & 0.076 \\
\hline \multirow{2}{*}{ Marketing Export } & $\mathrm{K}$ & 2.265 & 0.949 & 3.188 & 0.950 & $<0.001^{*}$ \\
& $\mathrm{~A}$ & 2.412 & 1.003 & 3.063 & 0.998 & $0.002^{*}$ \\
& $\mathrm{P}$ & 1.824 & 0.706 & 2.438 & 0.933 & $<0.001^{*}$
\end{tabular}

K- Knowledge, A- Attitude, P - Practice.

\subsection{Relevancy of the Training Module to Student Training}

The results of the central tendency for all items are shown in Table 5 The highest mean and standard deviation (SD) was 3.882 and 0.723 respectively. The lowest mean and SD were 3.324 and 0.403 respectively. The mean for relevancy of module ranges between 3.324 and 3.882 , thus indicating that the students found all modules very relevant to their training.

Table 5. Relevancy of the training module to the respondent

\begin{tabular}{lll}
\hline Process & Mean & SD \\
\hline Process chain management & 3.765 & 0.489 \\
Standards and certification & 3.794 & 0.404 \\
Product optimization & 3.765 & 0.424 \\
GMPs and hygiene & 3.882 & 0.403 \\
Quality control & 3.676 & 0.580 \\
Infrastructure development & 3.353 & 0.723 \\
Waste management & 3.647 & 0.681 \\
Product marketing & 3.324 & 0.674
\end{tabular}




\subsection{Practices Included in the University Curriculum}

The results of the mean scores for all the practices are shown in Table 6. ranged from 3.176-1.824. Students indicated that training in practices for skills in GMPs \& hygienic practices and waste management are well covered while practices in product optimization, quality control, and equipment are moderately taught. Practices in the documentation of the process chain, set-up of the processing facility, standardization, and certification of products and processes and marketing scored poorly and their training should be increased in the curriculum. Agricultural Engineering respondents rely their positive responses for waste management on the Environmental engineering course unit. Some of the practices are considered as part of the internship training and practical classes, especially with the Food Science and Technology respondents. Some nutrition respondents attribute their responses for waste management to a course in sanitation. Though not to a greater extent, some respondents agree to the fact that they attend some economic-related courses during their course of study, however, they don't focus on the marketing. This could explain the low score for both local and export marketing. Human nutrition respondents claim not to find many of these practices as part of their curriculum. Even to those that find some hints of the subjects within want they study; they are mainly theoretical. It is rather not surprising as human nutrition focuses more on good health, prevention, treatment, and management of diseases (MRC \& NHR, 2017) rather than the actual production of processed foods. Therefore, practices such as adequate processing facilities, adequate equipment, standardization, certification as well as marketing are not included in their curriculum.

Table 6. Level at which practices are included in the curriculum

\begin{tabular}{lll}
\hline Practice & Mean & SD \\
\hline Product optimization & 2.559 & 1.143 \\
Documented process chain & 2.235 & 1.190 \\
GMPs \& Hygienic practices & 3.176 & 1.042 \\
Quality control & 2.735 & 1.066 \\
Waste management & 3.176 & 1.124 \\
Adequate processing facility & 2.294 & 1.225 \\
Adequate equipment & 2.529 & 1.242 \\
Standardization & 2.176 & 1.224 \\
Certification & 1.824 & 1.175 \\
Marketing Local & 1.848 & 0.821 \\
Marketing Export & 1.912 & 0.818 \\
\hline
\end{tabular}




\subsection{How Best can These Modules be Included as Part of the Curriculum?}

The higher scores for relevancy of the modules (Table 5) indicate that these modules need to be availed to almost all the students. The respondents were tasked to suggest possible ways in which this important information can be given to students. The respondents suggested the following ways: (i) Inclusion of the modules as topics in the major course units. One of the respondents suggested that: "food engineering should accommodate a topic on equipment while food quality assurance should handle issues to do with plant design and plant layout"; (ii) Establishment of new course units to accommodate the content in the modules. Some respondents suggested that these can be taken as elective courses for those interested in joining the agro-processing industry; (iii) Establishment of online courses that can be accessed even after university; (iv) Through short training; (v) Through internships and recess term (Recess term is about 10 weeks between academic years at Makerere University. During this period, students are either placed at different industries for internship training or conduct on-campus practical training at the different laboratories and workshops); (vi) Provision of assignments to enable students to think critically about the content in the modules. Much as some respondents agree that these modules to some extent are already part of the curriculum, they continue to stress that the content is revised to include the new developments in the various fields thus making it applicable. Also, increasing the time allocated to some source units could help increase understanding of the different topics as part of the core course units. One of the respondents suggested that: "Environmental health and sanitation, a course unit taught in a recess should be rescheduled for a full semester, unlike 2 weeks. This course unit includes most of these modules but the time allocated to it is too little for most of these aspects to be covered. They just come as tangential discussions which do not yield much understanding."

\subsection{Other Modules that Could Be Included in the Training}

The study generally indicated that the training was well. However, the respondents noted that several other issues could have been included to enrich the training. Respondents suggested to include the following topics: (i) Gender and extension services; (ii) Product fortification; (iii) Post-harvest handling; (iv) Project planning and management; (iv) Monitoring and evaluation of business ventures; (iv) Case studies of established companies; (v) Energy utilization; and (vi) Communication skills.

\subsection{Aspects of the Training That Could Be Improved}

The respondents suggested the following improvements in the EAPI training: (i) Proper time management; (ii) Allocating more time for the delivery of modules; (iii) Providing training materials to the participants before or immediately after the training; (iv) Making the training more practical through vising the processing plant and use of videos clips. Improper time management by participants could have infringed on the actual and useful time for delivery of the modules as well as learning outcomes for the training as reported by Nasrullah and Khan (2015). Some studies are in agreement with the use of videos and other visual material for the delivery of information. According to Jensen, Holt, Sowards, Heath Ogden, and West (2018), the duo coding theory (where visual and audio are used) allows for more pathways through 
which the participant can interact with the material, therefore increasing the likelihood of remembering the content.

\subsection{What Changes Do You Anticipate Seeing in Your Academics as a Result of This Training?}

It is important to understand the long-term effect of the training on the attitudes of students. The respondents were asked to highlight critical changes that they foresaw in their academics as a result of the training. From the comments by respondents, there is evidence of changes in the mindset for students. Many students appreciated that whatever is taught in class can be translated into practice, therefore strengthening their interest in the theoretical classes. Some students hoped to make good choices as they continued with their studies at the master's level. One of the respondents wrote that "I was planning to do a Masters of Public Health Nutrition, but I will opt for a Masters of Food Safety and Quality Management." Another respondent wrote, "Change the way I look at different aspects because the training was an eye-opener. Now, I know where to put much effort to be successful."

\section{Conclusion}

The assessment showed that the students in the School of Food Technology Nutrition and Bio-Engineering (SFTNB), Makerere University, where highly impacted in their knowledge, attitude, and practice by the EAPI agro-processing skills training course. Students indicated for some of the targeted skills, they had either never had training or had received a few lessons (i.e., in Marketing, standardization \& certification, the layout of processing facilities, documentation in the food processing facility) or had undergone short training (i.e., in Good Manufacturing Practice and hygienic practices, Waste management, equipment, quality control). Generally, the practical aspects included within the curriculum is still inadequate. Students suggested that such integrated training should be embedded within their courses because it prepares them better for the workplace. Therefore, the inclusion of similar study material into the current curriculum would help improve and enrich the curriculum thereby producing well-prepared students for the food processing industry.

\section{Conflict of Interest}

The authors declare no conflict of interest.

\section{Acknowledgement}

This work was supported by the Government of Uganda through Makerere University Research and Innovation Fund (RIF) [grant number RIF1/CAES/008]. Special thanks to the various students of Makerere University for supporting this study.

\section{References}

Afurobi, A., Izuagba, A., Obiefuna, C., \& Ifegbo, P. (2015). Effects of the Use of Lecture Method and Wordle on the Performance of Students Taught Curriculum Studies 1: EDU222. Journal of Education and Practice, 6(18), 142-149.

Awang, H., \& Daud, Z. (2015). Improving a Communication Skill Through the Learning 
Approach Towards the Environment of Engineering Classroom. Procedia - Social and Behavioral Sciences, 195, 480-486. https://doi.org/10.1016/j.sbspro.2015.06.241

Dimitriada, A. (2013). Young women in science and technology: the importance of choice. Journal of Innovation and Entrepreneurship, 2(5). https://doi.org/10.1186/2192-5372-2-5

Etikan, I., Abubakar, S., \& Alkassim, S. (2016). Comparison of Convenience Sampling and Purposive Sampling. American Journal of Theoretical and Applied Statistics, 5(1), 1-4. https://doi.org/10.11648/j.ajtas.20160501.11

Gregory, J. L. (2013). Lecture is not a Dirty Word, How to Use Active Lecture to Increase Student Engagement. International Journal of Higher Education, 2(4), 116-122. https://doi.org/10.5430/ijhe.v2n4p116

Hussein, B. A., \& Ebru, A. (2016). Effects of Human Resources Training on Employee Perceived Performance: Comparison of Somalia-Turkiye Telekommunication Bussinesses. Archives of Business Research, 4(6), 1-15. https://doi.org/10.14738/abr.46.2331

Islam, M., Kim, D.-A., \& Kwon, M. (2020). A Comparison of Two Forms of Instruction: Pre-Recorded Video Lectures vs. Live ZOOM Lectures for Education in the Business Management Field. Sustainability, 12. https://doi.org/10.3390/su12198149

Jensen, J. L., Holt, E. A., Sowards, J. B., Heath Ogden, T., \& West, R. E. (2018). Investigating Strategies for Pre-Class Content Learning in a Flipped Classroom. Journal of Science Education and Technology, 27(6), 523-535. https://doi.org/10.1007/s10956-018-9740-6

Marinescu, P., \& Toma, S. G. (2013). Training Programs - Training and Development Alternatives for Students. Procedia Economics and Finance, 6, 306-312. https://doi.org/10.1016/S2212-5671(13)00144-5

Milhem, W., Abushamsich, K., \& Aróstegui, M. N. P. (2014). Training strategies, Theoriees, and Types. Journal of Accounting - Business \& Management, 21(1), 12 - 26.

MRC, \& NHR. (2017). Review of Nutrition and Human Health Research. Retrieved from https://mrc.ukri.org/documents/pdf/review-of-nutrition-and-human-health/

Muhwezi, G. (2020). UNBS destroys substandard goods worth UGX 2.5 Billion. Retrieved from https://blog.unbs.go.ug/?p=11241

Nasrullah, S., \& Khan, M. S. (2015). The Impact of Time Management on Students' Academic Achievement. Journal of Literature, Languages and Linguistics, 11, 66 - 71.

Nda, M. M., \& Fard, R. Y. (2013). The Impact of Employee Training and Development on Employee Productivity. Global Journal of Commerce and Management Perspective, 2(6), 91 $-93$.

Nunnally, J. C., \& Bernstein, I. H. (1994). Psychometric theory (3rd ed.). New York: McGrawHill. 


\section{Macrothink}

International Journal of Learning and Development

ISSN 2164-4063 2021, Vol. 11, No. 2

Riley, E. D., Bangsberg, D. R., Perry, S., Clark, R. A., Moss, A. R., \& Wu, A. W. (2003). Reliability and validity of the SF-36 in HIV-infected homeless and marginally housed individuals. Quality of Life Research, 12, 1051-1058. https://doi.org/10.1023/A:1026166021386

Sadeghi, R., Sedaghat, M., \& Sha Ahmadi, F. (2014). Comparison of the effect of lecture and blended teaching methods on students' learning and satisfaction. Journal of Advances in Medical Education \& Professionalism, 2(4), 146 - 150.

Salah, M. R. A. (2016). The Impact of Training and Development on Employees Performance and Productivity. International Journal of Management Sciences and Business Research, 5(7), $36-70$.

Shaaruddin, J., \& Mohamad, M. (2017). Identifying the Effectiveness of Active Learning Strategies and Benefits in Curriculum and Pedagogy Course for Undergraduate TESL Students. Creative Education, 08(14), 2312-2324. https://doi.org/10.4236/ce.2017.814158

Tiberious, M., Mwania, J. M., \& Mwinzi, J. (2016). The Influence of Financial Resources on the integration of the National Goals of Education. International Journal of Education and Research, 4(9), 51-62.

Zeng, H. L., Chen, D. X., Li, Q., \& Wang, X. Y. (2020). Effects of seminar teaching method versus lecture-based learning in medical education: A meta-analysis of randomized controlled trials. Medical Teacher, 42(12), 1343-1349. https://doi.org/10.1080/0142159X.2020.1805100 


\section{Appendix}

\section{SKILLS TRAINING EVALUATION FORM}

FOR PARTICIPANTS IN MAKERERE UNIVERSITY (MAK-RIF PROJECT)

Date:

\section{Purpose, consent and confidentiality clause}

The purpose of the study is to obtain information that will guide the evaluation and future improvement of the EAPI training course for students at Makerere University. You have been selected to participate in this study because you are participating in the EAPI training course. You are therefore requested to take off time and fill this questionnaire. Participation is voluntary and any information you provide will be used for study purposes ONLY and will be treated confidentially. You can choose not to answer any question you wish.

Do you consent to participate in this study (circle)? $\quad 1=$ Yes $\quad 2=$ No

Do you give permission to take and use photograph of you in any of the project publications and other content resulting from this study (circle)? $\quad 1=$ Yes $\quad 2=$ No

\section{Section 1: Demographics}

1.1 Name of Participant:

1.2 Gender (tick): $\square$ Male $\square$ Female

1.3 Program (tick): $\square$ AGE $\square$ FST $\square$ HNM $\square$ Other

1.4 Year of study (tick): $\square$ Undergraduate - second $\square$ Undergraduate - third $\square$ Undergraduate forth $\square$ Other (specify)

Section 2: Knowledge, Attitude and Practice (K - Knowledge in the field, A - Attitude in the field, P - Practice in the field)

2.1 In your journey as an agro-processing student, indicate your level of experience with the following fields or practice prior to the training. (Score from 1 - Never, 2 - Once in class, 3 - Short training, and 4 Very well)

\begin{tabular}{|l|l|l|l|l|l|l|}
\hline & & \multicolumn{5}{|c|}{ Rate (tick where applicable) } \\
\hline Field/Practice & & 1 & 2 & 3 & 4 \\
\hline Product optimization & K & & & & \\
\hline & A & & & & \\
\hline & P & & & & \\
\hline Documented process chain & K & & & & \\
\hline & A & & & & \\
\hline & P & & & & \\
\hline GMPs \& Hygienic practices & K & & & & \\
\hline & A & & & & \\
\hline
\end{tabular}




\begin{tabular}{|l|l|l|l|l|l|}
\hline & P & & & & \\
\hline & K & & & & \\
\hline & A & & & & \\
\hline & P & & & & \\
\hline & K & & & & \\
\hline & A & & & & \\
\hline & P & & & & \\
\hline Adequatity control management & K & & & & \\
\hline & A & & & & \\
\hline & P & & & & \\
\hline Adequate equipment & K & & & & \\
\hline & A & & & & \\
\hline & P & & & & \\
\hline Standardization & K & & & & \\
\hline & A & & & & \\
\hline & P & & & & \\
\hline Certification & K & & & & \\
\hline & A & & & & \\
\hline & P & & & & \\
\hline Marketing local & K & & & & \\
\hline & A & & & & \\
\hline & P & & & & \\
\hline Marketing Export & K & & & & \\
\hline & A & & & \\
\hline & P & & & & \\
\hline & & & & \\
\hline
\end{tabular}

2.2 To what extent were these practices developed after the training (Score from 1 - Not at all, 2 - To a small extent, 3 - Moderately, and 4 - To a great extent)

\begin{tabular}{|l|l|l|l|l|l|l|}
\hline & \multicolumn{7}{|c|}{ Rate (tick where applicable) } & Elaborate \\
\hline Field/Practice & & 1 & 2 & 3 & 4 & \\
\hline Product optimization & K & & & & & \\
\hline & $\mathrm{A}$ & & & & & \\
\hline & $\mathrm{P}$ & & & & & \\
\hline Documented process chain & $\mathrm{K}$ & & & & & \\
\hline & $\mathrm{A}$ & & & & & \\
\hline & $\mathrm{P}$ & & & & & \\
\hline GMPs \& Hygienic practices & $\mathrm{K}$ & & & & & \\
\hline & $\mathrm{A}$ & & & & & \\
\hline & $\mathrm{P}$ & & & & & \\
\hline Quality control & $\mathrm{K}$ & & & & & \\
\hline
\end{tabular}




\begin{tabular}{|l|l|l|l|l|l|l|}
\hline & A & & & & & \\
\hline & P & & & & & \\
\hline & K & & & & & \\
\hline & A & & & & & \\
\hline & P & & & & & \\
\hline & K & & & & & \\
\hline & A & & & & & \\
\hline & P & & & & & \\
\hline Adequate processing facility & K & & & & & \\
\hline & A & & & & & \\
\hline & P & & & & & \\
\hline Standardization equipment & K & & & & & \\
\hline & A & & & & & \\
\hline & P & & & & & \\
\hline Certification & K & & & & & \\
\hline & A & & & & & \\
\hline & P & & & & & \\
\hline Marketing local & K & & & & & \\
\hline & A & & & & & \\
\hline & P & & & & & \\
\hline Marketing Export & K & & & & & \\
\hline & A & & & & & \\
\hline & P & & & & & \\
\hline
\end{tabular}

\section{Section 3: Relevancy of the training module}

3.1 As a student, rate the level of relevancy for the modules delivered during the training (Score from 1 Not at all, 2 - To a small extent, 3 - Moderately, and 4 - To a great extent)

\begin{tabular}{|l|l|l|l|l|}
\hline & \multicolumn{5}{|c|}{ Rate (tick where applicable) } \\
\hline Field/Practice & 1 & 2 & 3 & 4 \\
\hline Process chain management & & & & \\
\hline Standards and certification & & & & \\
\hline Product optimization & & & & \\
\hline GMPs and hygiene & & & & \\
\hline Quality control & & & & \\
\hline Infrastructure development & & & & \\
\hline Waste management & & & & \\
\hline Product marketing & & & & \\
\hline
\end{tabular}




\section{Macrothink}

International Journal of Learning and Development

ISSN 2164-4063

2021, Vol. 11, No. 2

\section{Section 4: Practices included in the university curriculum}

4.1 Are any of these practices included in your curriculum? Rank the level of inclusion of the practices in the university curriculum (Score from 1 - Not at all, 2 - To a small extent, 3 - Moderately, and 4 - To a great extent)

\begin{tabular}{|c|c|c|c|c|c|}
\hline & \multicolumn{4}{|c|}{ Rate (tick where applicable) } & \multirow[t]{2}{*}{ Elaborate } \\
\hline Field/Practice & 1 & 2 & 3 & 4 & \\
\hline \multicolumn{6}{|c|}{ Product optimization } \\
\hline \multicolumn{6}{|c|}{ Documented process chain } \\
\hline \multicolumn{6}{|c|}{ GMPs \& Hygienic practices } \\
\hline \multicolumn{6}{|l|}{ Quality control } \\
\hline \multicolumn{6}{|l|}{ Waste management } \\
\hline \multicolumn{6}{|c|}{ Adequate processing facility } \\
\hline \multicolumn{6}{|c|}{ Adequate equipment } \\
\hline \multicolumn{6}{|l|}{ Standardization } \\
\hline \multicolumn{6}{|l|}{ Certification } \\
\hline \multicolumn{6}{|l|}{ Marketing local } \\
\hline Marketing Export & & & & & \\
\hline
\end{tabular}

Section 5: Inclusion of the modules into the university curriculum

5.1 In what ways do you think these modules should/could be included in your curriculum?

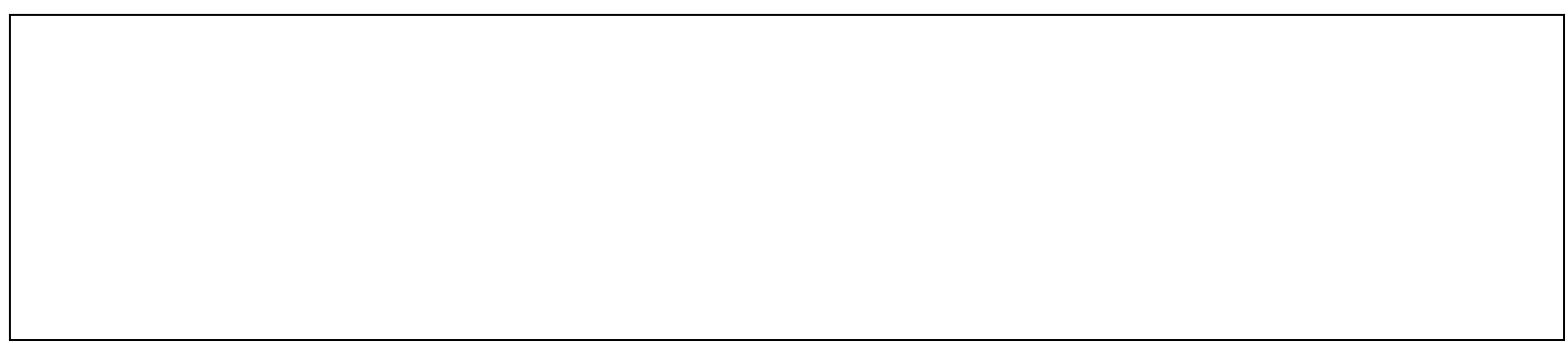

Section 6: Other modules that need to be added to the training

6.1 Which other modules in relation to agro-processing would you want included in this training?

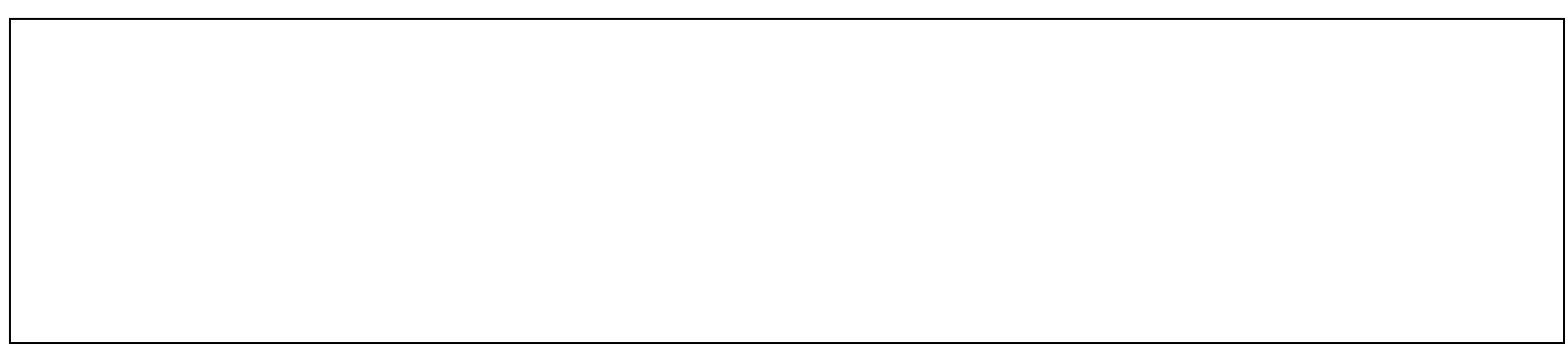

\section{Section 7: Improvement of the training}

7.1 What aspects of the training do you think can be improved to make it more resourceful? 
Section 8: Anticipated changes among students' academic performance

8.1 What changes do you anticipate seeing in your academics as a result of this training?

\section{Thank you}

\section{Copyright Disclaimer}

Copyright for this article is retained by the author(s), with first publication rights granted to the journal.

This is an open-access article distributed under the terms and conditions of the Creative Commons Attribution license (http://creativecommons.org/licenses/by/4.0/). 